\title{
Unusual F-I 8 FDG Uptake at the Ears of a Patient with Discoid Lupus Erythematosus
}

\author{
Diskoid Lupus Eritamatozus Olgusunda Kulaklarda Olağan Dışı Artmış F-I 8 FDG Tutulumu
}

\author{
Tamer Özülkerl, Filiz Özülkerl, Filiz Cebeci2, Adnan Somay33, Mehmet Tank Tatoğlul, Tevfik Özpaçacıl \\ IOkmeydanı Educational and Research Hospital, Department of Nuclear Medicine, Istanbul, Turkey \\ 2Bezmialem Vakif University Faculty of Medicine, Department of Dermatology, Istanbul, Turkey \\ 3Bezmialem Vakıf University Faculty of Medicine, Department of Pathology, Istanbul, Turkey
}

\begin{abstract}
A 55-year-old patient, who had undergone excisional biopsy of upper lip two years ago and diagnosed to have squamous cell carcinoma, was referred to us for evaluation with Fluorine-18 fluorodeoxyglucose (F-18 FDG) positron emission tomography (PET)/CT (F-18 FDG-PET/CT) scan. F-18 FDG-PET/CT scan was performed and the maximum intensity projection images (MIP) showed unusual FDG uptake at both ears. Histopathological examination of the biopsy specimen obtained from the ears revealed discoid lupus erythematosus (DLE). (MIRT 2012;21:29-31)
\end{abstract}

Key words: Positron-emission tomography, lupus erythematosus, discoid, fluorodeoxyglucose F-18

\section{Özet}

İki yıl önce üst dudaktan eksizyonel biyopsi yapılarak skuamöz hücreli karsinom tanısı alan 55 yasındaki erkek hasta, Flor-18 florodeoksiglukoz (F-18 FDG) pozitron emisyon tomografisi (PET)/BT (F-18 FDG-PET/BT) tetkiki ile değerlendirilmek üzere kliniğimize sevk edilmiş. F-18 FDG-PET/BT tetkiki maksimum intensite projeksiyon görüntülerinde (MIP) her iki kulakta olağan dışı artmış FDG tutulumu izlendi. Kulaktan alınan biyopsi numunesinin patolojik incelemesinde diskoid lupus eritematozus (DLE) tanıSI elde edildi. (MIRT 2012:21:29-31)

Anahtar kelimeler: Pozitron emisyon tomografi, lupus eritematozus, diskoid, fluorodeoksiglukoz F-18

\section{Introduction}

Discoid lupus erythematosus (DLE) is a chronic and inflammatory dermatosis which may progress to systemic lupus erythematosus (SLE). F-18 FDG-PET/CT has been shown to demonstrate inflammation via the increased glucose uptake ability of granulocytes and tissue macrophages (1). Here we present a case of DLE in which increased F-18 FDG uptake at the ears of a patient was detected probably because of this FDG avidity of inflammatory cells.

\section{Case Report}

A 55-year-old patient, who had undergone excisional biopsy of upper lip two years ago and diagnosed to have squamous cell carcinoma, was referred to us for evaluation with F-18 FDG-PET/CT scan. On physical examination, there were erythematous scaly lesions on the face, especially on the ears, telangiectasias on the cheek and rash on the bridge of the nose. Additionally, there were plaques, extending from the cheek to the neck, with scaly centers lighter in color and with dark edge (Figure 1). Anamnesis of the patient revealed that these lesions had been present for twenty-five years and the patient had used topical steroids irregularly. F-18 FDG-PET/CT scan was performed and unusual FDG uptake was detected at both ears. There was also nonspecific uptake at mediastinal lymph nodes (Figure 2). Histopathological examination

Address for Correspondence: Tamer Özülker MD, Okmeydanı Educational and Research Hospital, Department of Nuclear Medicine, İstanbul, Turkey Gsm: +90 5063026157 E-mail: tozulker@ttmail.com

Received: 23.04.2011 Accepted: 15.10.2011 
of the biopsy specimen obtained from the ears revealed hyperkeratotic epidermis and perivascular and perifollicular moderate inflammatory cell infiltration at upper and medium dermis (Figure 3). Further laboratory examinations showed no evidence, suggesting SLE and the case was diagnosed as DLE with these clinical and histopathological findings.

\section{Literature Review and Discussion}

The utility of F-18 FDG-PET/CT in patients with SLE has been limited to the central nervous system $(2,3,4,5)$. In one study, PET scans showed hypometabolism in at least one brain region in all patients with severe or mild CNS symptoms (100\%) and the authors decided that PET imaging represents a sensitive tool to detect manifest or subclinical CNS involvement in SLE and PET findings correlate well with the clinical course of disease (6). F-18 FDG-PET can identify fluctuations in regional cerebral metabolism in neuropsychiatric SLE (NP-SLE) patients, even when no structural lesions are evident on magnetic resonance imaging (MRI) (3). Computed tomography (CT) or MRI have been found to be useful in the detection of focal neurological deficits rather than diffuse presentations in patients with SLE $(7,8,9)$. It was shown that FDG-PET could help to verify brain-onset of SLE earlier and it might also be a powerful tool for controlling SLE treatment (10). FDG-PET is shown to be more sensitive than MRI and CT in the diagnosis of NP-SLE, with its ability of demonstrating even reversible deficits and showing a better correlation with other neurological findings (11). DLE is an autoimmune inflammatory disorder of the skin that often leads to scarring and alopecia. While about $15 \%$ to $20 \%$

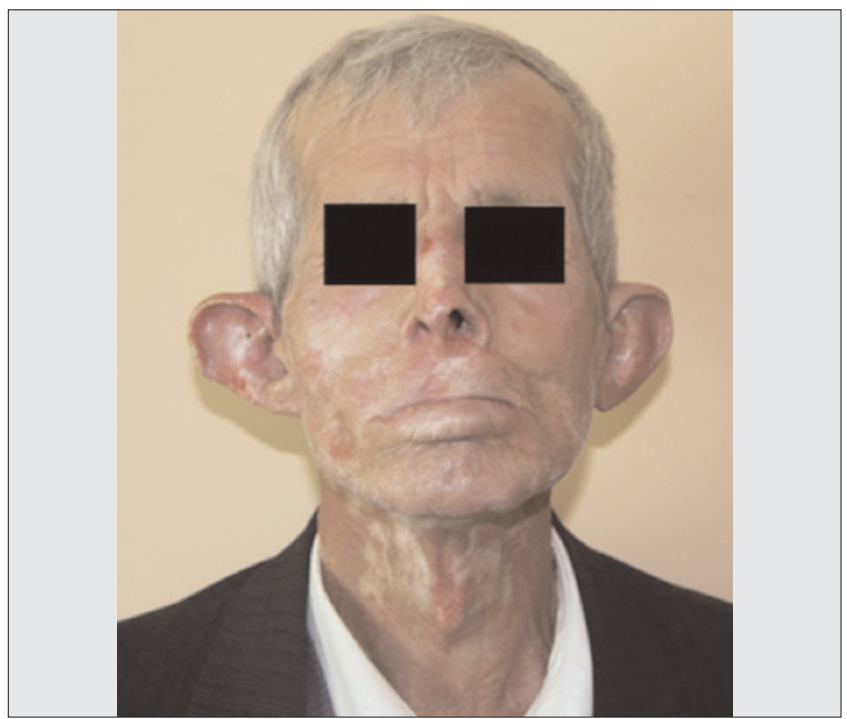

Figure 1. Patient with discoid lupus erythematosus

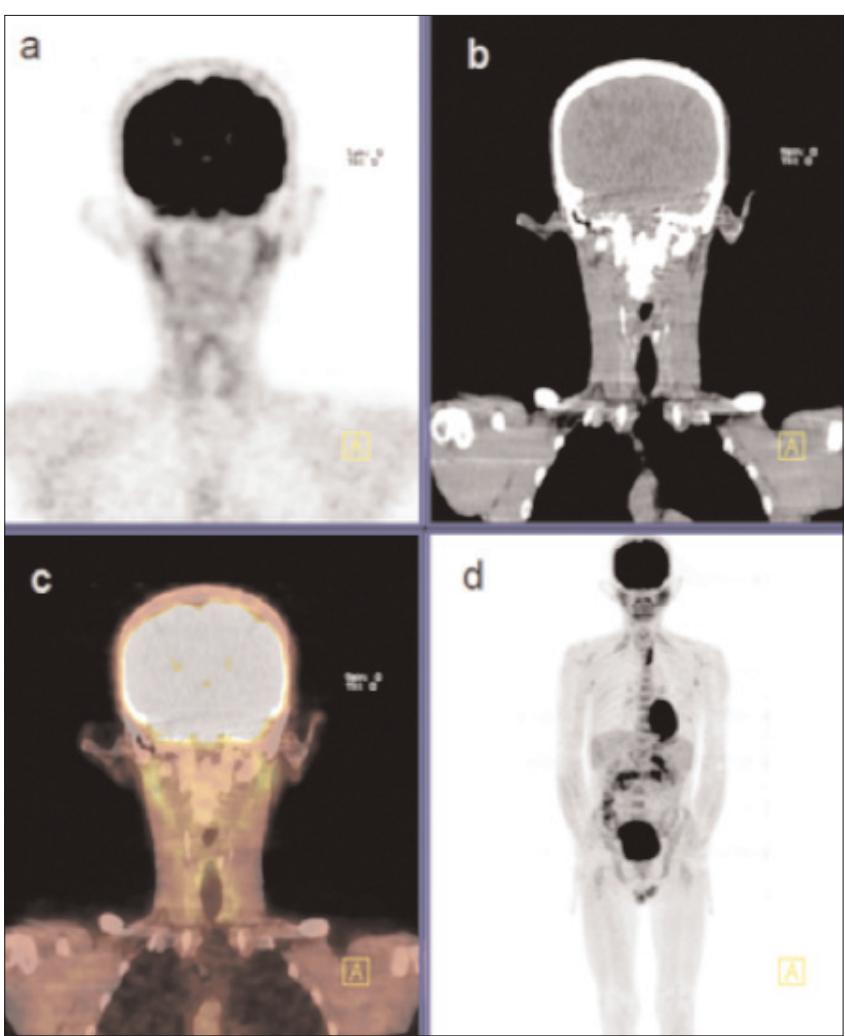

Figure 2. PET (a), CT (b), fusion (c) and MIP (d) images of the patient showing unusual uptake at ears and nonspecific uptake at mediastinum

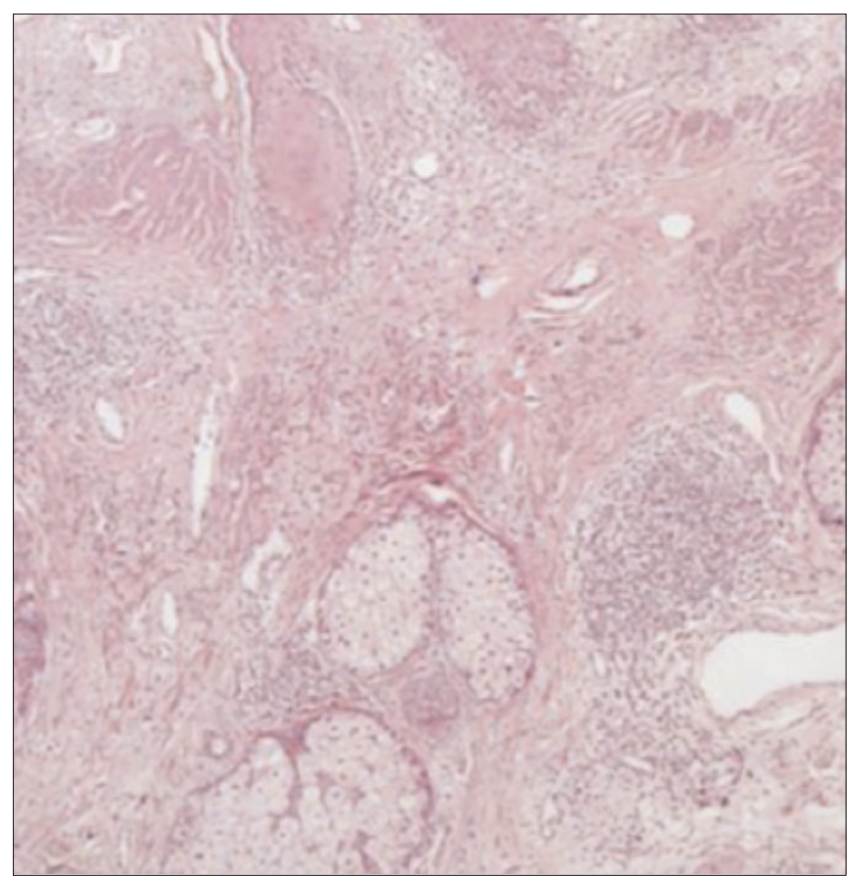

Figure 3. Histopathological examination of the biopsy specimen obtained from the ears showing hyperkeratotic epidermis and perivascular and perifollicular moderate inflammatory cell infiltration at upper and medium dermis H\&E x 100 
of patients with SLE manifest DLE lesions, only about $5 \%$ to $10 \%$ of patients with DLE go on to develop SLE (12). Classic DLE is the most common form of chronic cutaneous lupus erythematosus (CCLE) (13). Inflammatory cells have been reported to have an increased uptake of $\mathrm{F}$ 18 FDG (14) and this is likely to be the mechanism responsible for FDG uptake at the ears of our patient. Today, we do not have enough knowledge about the significance of this incidental FDG uptake at the ears. It has been reported that both patients with active lupus and those with inactive lupus had increased FDG uptake in lymph nodes when compared with healthy volunteers so F-18 FDG$\mathrm{PET} / \mathrm{CT}$ can not distinguish active and clinically quiescent disease (15). To our knowledge, this is the first case in the literature showing F-18 FDG uptake at lesions of DLE and further studies might be helpful to detect any possible role of F-18 FDG-PET/CT in the evaluation of the activity and severity of DLE.

\section{References}

1. Love C, Tomas MB, Tronco GG, Palestro CJ. FDG PET of infection and inflammation. Radiographics. 2005;25:1357-68.

2. Meyer GJ, Schober O, Stoppe G, Wildhagen K, Seidel JW, Hundeshagen $H$. Cerebral involvement in systemic lupus erythematosus (SLE): comparison of positron emission tomography (PET) with other imaging methods. Psychiatry Res 1989;29:367-368.

3. Stoppe G, Wildhagen K, Seidel JW, Meyer GJ, Schober O, Heintz $P$, Künkel $H$, Deicher $H$, Hundeshagen $H$. Positron emission tomography in neuropsychiatric lupus erythematosus. Neurology 1990;40:304-308.

4. Otte A, Weiner SM, Peter HH, Mueller-Brand J, Goetze M, Moser E, Gutfleisch J, Hoegerle S, Juengling FD, Nitzsche EU. Brain glucose utilization in systemic lupus erythematosus with neuropsychiatric symptoms: a controlled positron emission tomography study. Eur J Nucl Med 1997;24:787-791.

5. Grunwald F, Schomburg A, Badali A, Ruhlmann J, Pavics L, Biersack HJ. 18FDG PET and acetazolamide-enhanced 99mTcHMPAO SPET in systemic lupus erythematosus. Eur J Nucl Med 1995;22:1073-1077.
6. Weiner SM, Otte A, Schumacher M, Klein R, Gutfleisch J, Brink I, Otto P, Nitzsche EU, Moser E, Peter HH. Diagnosis and monitoring of central nervous system involvement in systemic lupus erythematosus: value of F-18 fluorodeoxyglucose PET. Ann Rheum Dis 2000;59:377-385.

7. Stimmler MM, Coletti PM, Quismorio FP Jr. Magnetic resonance imaging of the brain in neuropsychiatric systemic lupus erythematosus. Semin Arthritis Rheum 1993;22:335-349.

8. West SG, EmlenW,Wener MH, Kotzin BL. Neuropsychiatric lupus erythematosus: a 10-year prospective study on the value of diagnostic tests. Am J Med 1995;99:153-163.

9. Kozora E,West SG, Kotzin BL, Julian L, Porter S, Bigler E. Magnetic resonance imaging abnormalities and cognitive deficits in systemic lupus erythematosus patients without overt central nervous system disease. Arthritis Rheum 1998;41:41-47.

10. Otte A, Weiner SM, Hoegerle S, Wolf $R$, Juengling FD, Peter $H H$, Nitzsche EU. Neuropsychiatric systemic lupus erythematosus before and after immunosuppressive treatment: a FDG PET study. Lupus 1998;7:57-59.

11. Stoppe G, Wildhagen K, Meyer GJ, Schober O. Use of fluorodeoxyglucose PET in the diagnosis of central nervous system lupus erythematosus and a comparison with $\mathrm{CT}$ and MRI. Nuklearmedizin 1989;28:187-192.

12. Callen JP. Systemic lupus erythematosus in patients with chronic cutaneous (discoid) lupus erythematosus. Clinical and laboratory findings in seventeen patients. J Am Acad Dermatol $1985 ; 12: 278-288$

13. Walling HW, Sontheimer RD. Cutaneous lupus erythematosus: issues in diagnosis and treatment. Am J Clin Dermatol 2009;10:365-381.

14. Shreve PD, Anzai Y, Wahl RL. Pitfalls in oncologic diagnosis with FDG PET imaging: physiologic and benign variants. Radiographics 1999;19:61-77.

15. Nowak M, Carrasquillo JA, Yarboro CH, Bacharach SL, Whatley M, Valencia X, Takada K, Brust DG, Illei GG. A pilot study of the use of 2-(18F)-fluoro-2-deoxy-D-glucose-positron emission tomography to assess the distribution of activated lymphocytes in patients with systemic lupus erythematosus. Arthritis Rheum 2004;50:1233-1238. 